\title{
Pengaruh Sinbiotik untuk Aditif Pakan Ayam Petelur terhadap Kandungan Kimiawi Telur
}

\section{Effect a sinbiotik for feed additive for laying hens on the content of Chemical eggs}

\author{
E. M. A. Sari*, E. Suprijatna dan W. Sarengat \\ Fakultas Peternakan dan Pertanian, Universitas Diponegoro, Semarang, 50275 \\ *E-mail: egamufit@gmail.com \\ (Diterima: 13 Oktober 2016; Disetujui: 10 Januari 2017)
}

\begin{abstract}
ABSTRAK
Penelitian bertujuan untuk mengetahui pengaruh penambahan sinbiotik sebagai aditif pakan ayam petelur terhadap kandungan kimiawi telur. Materi yang digunakan adalaha ayam ras petelur dengan umur 40 minggu dengan $\mathrm{BB}$ rata - rata $1815 \pm 0.12 \mathrm{~g}(\mathrm{CV}=6.65 \%)$ sebanyak 100 ekor. Rancangan percobaan yang digunakan adalah Rancangan Acak Lengkap dengan 4 perlakuan dan 5 kali ulangan dan setiap ulangan terdiri dari 5 ekor ayam. Perlakuan yang dgunakan adalah penambahan sinbiotik dengan level $0 \%, 0.5 \%, 1 \%$ dan $1,5 \%$ Parameter yang diamati adalah kandungan protein putih telur, lemak kuning telur, dan kolesterol kuning telur. Data yang diperoleh dianalisis menggunakan analisis ragam dan uji $\mathrm{F}$ pada taraf $5 \%$. Hasil analisis varian menunjukkan bahwa penambahan sinbiotik tidak berpengaruh nyata terhadap kandungan protein putih telur dan lemak kuning telur $(\mathrm{P}>0,05)$, sedangkan untuk kolesterol kuning telur berpengaruh nyata $(\mathrm{P}<0,05)$. Kesimpulan dari penelitian ini adalah penambahan sinbiotik sebagai aditif pakan ayam petelur tidak berpengaruh terhadap kandungan protein putih telur, lemak kuning telur, dan kolesterol kuning telur.
\end{abstract}

Kata kunci: ayam petelur, sinbiotik, protein, lemak, kolesterol telur

\section{ABSTRACT}

The Research was conducted to determine the effect of waste Industrial Herbal Medicine and Lactic Acid Bacteria (Lactobacillus Sp.) namely sinbiotik as one of feed additive for laying hens on the content of chemical eggs. The materials used were 100 laying hens of 40 weeks old with averages weight $1815 \pm 0.12$ $g(C V=6.65 \%)$. The experimental design was a Completely Randomized Design with 4 treatments and 5 replication, and each treatment consisted 5 laying hens. The treatments were sinbiotik addition levels that is $0 \%, 0.5 \%, 1 \%$ and $1.5 \%$. The variables observed were the contents of egg albumen protein, fat level of egg yolk and the cholesterol level of egg yolk no significant $(P>0.05)$ was found between treatments in term protein level of egg albumen and fat level of egg yolk, but there was a significant effect $(P<0.05)$ between treatments in term cholesterol level of egg yolk. In conclusion the addition of sinbiotik as feed additive for laying hens could not decrease protein level of egg albumen, fat level on egg yolk and cholesterol level of egg yolk.

Keywords: Laying hens, synbiotic, protein, fat cholesterol eggs

\section{PENDAHULUAN}

Pengembangan usaha peternakan di Indonesia khususnya peternakan ayam petelur semakin berkembang, namun terdapat hambatan yaitu adanya faktor iklim tropis di Indonesia. Faktor temperatur lingkungan dan kelembaban yang tinggi dapat meningkatkan tingkat stress ayam sehingga konsumsi pakan menurun dan menyebabkan menurunnya pula tingkat produktivitas (Nuriyasa et al., 2010).

Upaya yang dilakukan untuk mengatasi efisiensi penggunaan pakan ayam sehingga produktivitas dan kesehatan ayam dapat terjaga yaitu dengan cara penambahan aditiv dalam pakan, salah satunya yaitu penggunaan sinbiotik. Dewasa ini sering digunakan probiotik dan prebiotik sebagai tambahan zat 
aditive dalam upaya meningkatkan efisiensi pakan ayam petelur (Amani et al., 2013).

Penggunaan zat aditif dalam ransum pakan sejauh ini masih terpisah antara penggunaan probiotik dan prebiotik sehingga pelaksanaannya dinilai kurang praktis dan perlu adanya upaya penggabungan kedua bahan antara prebiotik dan probitoik supaya fungsi atau sasaran dari kedua bahan tersebut dapat bekerja secara maksimal, menjadi sebuah sinbiotik. Sinbiotik merupakan kombinasi antara probiotik dan prebiotik, yang merupakan subsrat yang dapat mengubah mikroekologi usus sehingga mikroba yang menguntungkan dapat berkembang secara baik (Kompiang, 2009). Probiotik merupakan sekumpulan mikrobia yang menguntungkan yang dapat hidup didalam usus dan saling menguntungkan untukn inangnya baik secara langsung mapun tidak langsung dari metabolitnya (Kompiang, 2009). Prebiotik merupakan sumber energi atau nutrien bagi mikroba untuk meningkatkan keseimbangan mikroba dalam saluran pencernaan (Haryati, 2011). Penggunaan sinbiotik diharapkan mampu meningkatkan kecernaan nutrien, sehingga nutrein yang diserap oleh ayam petelur dapat meningkatkan dan diharapkan mampu memperbaiki kandungan nutrien telur. kandungan nutrisi telur bergantung dari ransum yang diberikan.

Limbahjamu potensial sebagai prebiotik karena di dalam limbah jamu terdapat senyawa oligosakarida dan antioksidan. Oligosakarida merupakan senyawa yang dapat dimanfaatkan untuk nutrisi Bakteri Asam Laktat (BAL). Oligosakarida merupakan komponen yang utama dalam prebiotik (Haryati, 2011). Proses pembuatan jamu harus melalui tahap ekstraksi yang menyebabkan zat aktif dalam jamu tersebut ikut terekstraksi sehingga tersisa serat kasar seperti glikosida (Zainudin, 2006). Kondisi saat ini limbah jamu belum dimanfaatkan secara optimal, sehingga perlu dilakukan penelitian limbah jamu sebagai prebioik dengan memanfaatkan BAL untuk menghasilkan sinbiotik.

Galik et al. (2014) yang menunjukkan bahwa pemberian aditif dalam pakan ayam petelur berpengaruh signifikan terhadap kandungan kolesterol kuning telur, pemberian aditif mampu menurunkan kandungan kolesterol kuning telur. Pemberian probiotik berdampak positif terhadap kualitas produk daging dan telur dnegan kandungan kolesterol lebih rendah, serta bebas residu antibiotik Salmonella atau patogen lain (Kompiang, 2009). Oleh karena itu penggunaan sinbiotik dengan memanfaatkan limbah jamu dan BAL perlu diamati terhadap kandungan kimiawi telur.

Telur unggas mengandung banyak nutrisi seperti protein, lipid, vitamin, mineral dan beberapa kebutuhan nutrisi yang dibutuhkan untuk perkembangan embrio (Bologa et al., 2009). Telur terdiri dari tiga bagian yaitu kulit telur dengan berat $11 \%$, putih telur $58 \%$ dan kuning telur sekitar 31\%, kandungan dan komposisi kimia masing masing bagian berbeda, perbedaan komposisi kimia tersebut disebabkan oleh ransum yang dikonsumsi, umur, faktor lingkungan dan laju produksi (Ariyani, 2006).

Kandungan komposisi telur terdiri dari air sebesar 73,7\%, Protein $12,9 \%$, lemak $11,2 \%$ dan karbohidrat $0,9 \%$, pengamatan lemak dan kolesterol efektif dilakukan pada kuning telur, karena pada putih telur lemaknya sedikit (Muharlien, 2010). Kandungan kimia telur dapat dipengaruhi oleh tingkat kecernaan nutrien dari ayam petelur. Penambahan sinbiotik sebagai aditif pakan ayam petelur diharapkan mampu meningkatkan kecernaan nutrien sehingga akan berpengaruh baik atau meningkatkan kandungan kimawi telur. Ayam petelur putih memiliki kandungan kadar kolesterol 17,41 mg per gran kuning telur, sedangkan ayam petelur coklat menghasilkan kadar kolesterol 17,08 mg per gram kuning telur (Ariyani, 2006).

Penelitian ini bertujuan untuk mengetahui kualitas kimiawi telur, dilihat dari aspek kandungan protein putih telur, lemak kuning telur dan kolesterol kuning telur. Manfaat penelitian ini yaitu diperoleh informasi mengenai pemanfaatan limbah 
jamu dan bakteri asam laktat sebagai sinbiotik untuk memeperbaiki kandungan kimiawi telur.

\section{METODE}

Penelitian dilakukan pada bulan Oktober-Desember 2016 di Kandang penelitian CV. Pupular Farm Boja Kendal. Materi penelitian menggunakan 100 ekor ayam petelur berumur 40 minggu dengan bobo badan rata - rata $1815 \pm 0.12(\mathrm{CV}=$ $6.65 \%$ ). Ransum yang digunakan dalam penelitian tersusun dari tepung jangung, bekatul, bungkil kedelai, mbm, premix dan tambahan sinbiotik sebagai aditif.

Pembuatan sinbiotik adalah menggunakan prebitoik berupa limbah jamu berupa tepung dan probitoik berupa BAL berupa cairan. Penggabungan prebiotik dan probotik dilakukan dengan dosis $150 \mathrm{ml}$ probiotik/kg prebiotik, dengan kandungan BAL $2.67 \times 10^{7} \mathrm{cfu} / \mathrm{g}$. Sinbiotik yang dihasilkan berupa tepung. Limbah jamu diperoleh dari pabrik Sidomuncul Pupuk Nusantara Bawen
Semarang.

Metode yang digunakan yaitu percobaan Rancangan Acak Lengkap dengan 4 perlakuan dengan 5 kali ulangan. Perlakuan yang diberikan:

T0 : Ransum $+0 \%$ sinbiotik

$\mathrm{T} 1:$ Ransum $+0,5 \%$ sinbiotik

$\mathrm{T} 2:$ Ransum $+1 \%$ sinbiotik

$\mathrm{T} 3$ : Ransum $+1,5 \%$ sinbiotik

Air minum diberikan secara adlibitum selama 60 hari penelitian.

Data dianalisis menggunakan Analisis Ragam, jika terdapat pengaruh perlakuan dilanjutkan dengan Uji Duncan. Pengamatan parameter meliputi kandungan protein putih telur, lemak kuning telur dan kolesterol kuning telur. Metode yang dilakukan untuk mengetahui kandungan protein putih telur, lemak kuning telur dan kolesterol kuning telur yaitu :

Kadar protein putih telur: analisis kandungan protein dilakukan pada minggu terakhir penelitian pada ayam umur ke -48 minggu, analisis di lakukan di laboratorium Sidomuncul Pupuk Nusantara menggunakan

Tabel 1. Komposisi dan kandungan nutrien ransum penelitian.

\begin{tabular}{lcccc}
\hline Komposisi Bahan Pakan & T0 & T1 & T2 & T3 \\
\hline Jagung (\%) & 53,80 & 53,80 & 53,80 & 53,80 \\
Bungkil Kedelai (\%) & 18,93 & 18,93 & 18,93 & 18,93 \\
Bekatul (\%) & 1,86 & 11,86 & 11,86 & 11,86 \\
Meat Bone Meal (\%) & 5,99 & 5,99 & 5,99 & 5,99 \\
Grit (\%) & 8,40 & 8,40 & 8,40 & 8,40 \\
Premix (\%) & 1,00 & 1,00 & 1,00 & 1,00 \\
\hline Jumlah & 100,00 & 100,00 & 100,00 & 100,00 \\
\hline Sinbiotik & 0,00 & 0,50 & 1,00 & 1,50 \\
\hline Jumlah Setelah Penambahan Sinbiotik & 100,00 & 100,50 & 101,00 & 101,50 \\
\hline Kandungan Nutrisi dalam Ransum & & & & \\
\hline Lemak Kasar (\%) & 2,641 & $2,63^{*}$ & $2,61^{*}$ & $2,60^{*}$ \\
Serat Kasar (\%) & 4,69 & $4,66^{*}$ & $4,64^{*}$ & $4,62^{*}$ \\
Protein Kasar (\%) & 17,44 & $17,35^{*}$ & $17,27^{*}$ & $17,18^{*}$ \\
Kadar Abu (\%) & 13,73 & $13,67^{*}$ & $13,60^{*}$ & $13,54^{*}$ \\
Kadar Air (\%) & 10,62 & $10,57^{*}$ & $10,51^{*}$ & $10,46^{*}$ \\
Energi Metabolisme (kkal/kg) & 3213,19 & $3197,20^{*}$ & $3181.38^{*}$ & $3165,70^{*}$ \\
\hline
\end{tabular}

Keterangan :

${ }^{1}$ Hasil Analisis Laboratorium Ilmu Nutrisi Pakan FPP Undip (2017)

${ }^{2}$ Hasil Analisis Laboratorium Sidomuncul Pupuk Nusantara Bawen Semarang (2016)

${ }^{3} \mathrm{EM}$ dihitung menggunakan rumus balton :

$\mathrm{EM}(\mathrm{kkal} / \mathrm{kg})=40.81[0.87(\mathrm{PK}+2.25 \mathrm{x} \mathrm{LK}+\mathrm{BETN})+\mathrm{K}]($ Indreswari et al.,2009)

*Hasil Perhitungan sudah disetarakan kedalam 100\%. 
metode Mikro-Kjeldhal.

Lemak kuning telur: analisis kandungan lemak kuning telur menggunakan metode Soxhlet, dengan prinsip sample di hidrolisis dengan asam klorida untuk melepaskan lemak yang terikat.

Kandungan kolesterol kuning telur dilakukan di Laboratorium Ilmu Nutrisi Pakan FPP Undip, kandungan kolesterol diperoleh dengan cara sample sebanyak \pm 1 gram dalam tabung erlenmeyer ditambah $10 \mathrm{ml}$ propanol dan $20 \mathrm{ml} \mathrm{KOH}_{5}$, kemudian di panaskan dalam penangas air pada temperatur $30-40^{\circ} \mathrm{C}$ untuk proses saponifikasi elama 30 menit. Sebanyak $2 \mu$ larutan ekstrak kuning telur dipipet kedalam tabung reaksi ditambahkan $2 \mathrm{ml}$ kit kolesterol, ditunggu 10 menit kemudian diukur absorbans (ABS) sample manggunakan spektrofotometer, menghitung kandungan kolesterol dengan rumus :

$$
\begin{aligned}
& \text { konsentrasi kolesterol }=\frac{\text { ABS Sample }}{\text { AES Standar }} \times 200 \\
& \text { Kadar kolesterol }(\mathrm{mg} / \mathrm{g})= \\
& \frac{\text { Konsontrast } x \text { volume indukan }}{\text { borat sampla }}
\end{aligned}
$$

\section{HASIL DAN PEMBAHASAN}

Data hasil pengamatan pengaruh penambahan sinbiotik terhadap kandungan protein putih telur, lemak kuning telur dan kolesterol kuning telur di sajikan pada Tabel 2.

Berdasarkan hasil penelitian diperoleh rata - rata kandungan protein putih telur yaitu 9.07\%. Hasil penelitian ini menunjukkan bahwa pemberian sinbiotik tidak berpengaruh terhadap kandungan protein putih telur dan tidak jauh dengan kisaran normal. Kisaran normal kandungan protein putih telur yaitu $9.70-10.60 \%$ (Bell dan Weaver, 2002). Hasil analisis ragam menunjukkan bahwa perlakuan tidak berpengaruh nyata terhadap kandungan protein putih telur $(\mathrm{P}>0.05)$. Penelitian ini berbeda dengan penelitian yang telah dilakukan oleh Sathya dan Muruguian (2015) tentang suplementasi probiotik dan Curculigo orchioides rhizome powder terhadap kualitas telur puyuh yang menunjukkan hasil bahwa kandungan protein putih telur puyuh lebih tinggi pada perlakuan pemberian probiotik, jika dibandingkan dengan perlakuan kontrol. Perbedaan hasil penelitian disebabkan karena pada penelitian ini prebiotik yang digunakan berasal dari limbah jamu. Limbah jamu sebagai prebiotik belum cukup untuk mencukupi kebutuhan nutrisi bagi BAL sehingga tidak optimal dalam meningkatkan kecernaan protein, dan berakibat belum mampu memperbaiki atau meningkatkan kandungan protein putih telur. Sementara pada penelitian Sathya dan Muruguaian (2015) penggunaan jenis tepung rimpang Curculigo orchioides dapat meningkatkan kandungan protein telur.

Faktor lain yang dapat berpengaruh yaitu kemampuan unggas dalam mempertahankan kandungan protein telur saat proses deposisi. Menurut Suprijatna et al. (2008) komposisi telur sepanjang tahun agak konstan, namun terjadi sedikitnya perubahan energi dan vitamin tertentu dan mineral akibat berkurangnya pakan. Kandungan protein putih telur dapat dipengaruhi oleh kandungan dan komposisi protein ransum. Berdasarkan hasil analisis kandungan protein ransum sebesar 17.\% dan kandungan komposisi limbah jamu $8.69 \%$. Asam - asam amino dari pakan yang telah diserap didalam hati kemudian akan dibentuk menjadi protein dan di salurkan ke ovarium untuk proes pembentukan telur (Ujilestari, 2015).

Pengukuran kandungan lemak pada telur dilakukan pada kuning telur, hal tersebut dilakukan karena lemak yang terkandung dalam telur sebagian besar ada pada kuning telur. Hal tersebut sesuai dengan penelitian yang dilakukan oleh Muharlien (2010) bahwa pengamatan lemak pada telur lebih efektif dilakukan pada kuning telur karena hampir semua lemak di dalam telur terdapat di kuning telur mencapai $32 \%$, sedangkan untuk putih telur kandungan lemaknya sedikit.

Hasil analisis ragam menunjukkan bahwa perlakuan tidak berpengaruh nyata 
Tabel 2. Rataan kadar protein putih telur, lemak dan kolesterol kuning telur.

\begin{tabular}{lcccc}
\hline \multirow{2}{*}{ Parameter } & \multicolumn{4}{c}{ Perlakuan } \\
\cline { 2 - 5 } & T0 & T1 & T2 & T3 \\
\hline Protein Putih Telur (\%) & $9.19 \pm 1.05$ & $8.66 \pm 1.86$ & $9.10 \pm 1.13$ & $9.35 \pm 1.38$ \\
Lemak Kuning Telur (\%) & $29.03 \pm 0.69$ & $28.03 \pm 2.17$ & $27.71 \pm 2.92$ & $28.55 \pm 2.44$ \\
Kolesterol Kuning Telur (mg/g) & $16.68 \pm 3.88^{\mathrm{b}}$ & $21.04 \pm 1.65^{\mathrm{a}}$ & $15.26 \pm 1.71^{\mathrm{b}}$ & $14.39 \pm 1.71^{\mathrm{b}}$ \\
\hline
\end{tabular}

Keterangan : Notasi yang berbeda pada baris yang sama menunjukkan perbedaan yang nyata $(\mathrm{P}<0.05)$

terhadap kandungan lemak kuning telur $(\mathrm{P}>0.05)$. Hasil penelitian kandungan lemak kuning telur relatif lebih rendah jika dibandingkan dengan hasil penelitian Tolik et al. (2014) yang menyatakan bahwa kandungan lemak kuning telur yaitu $32.6 \%$. Hal ini sesuai dengan pendapat Lai et al. (2010) bahwa kandungan lemak dalam kuning telur ayam berkisar antara 31-8 - 35-5\%.

Rendahnya kadar lemak kuning telur dapat terjadi karena pengaruh dari sinbiotik yang merupakan campuran dari prebiotik berupa limbah jamu dan probiotik dari bakteri asam laktat. Hal ini sesuai dengan pendapat Zeweil et al. (2005) yang menyatakan bahwa penambahan probiotik dalam pakan puyuh tidak memberikan pengaruh nyata terhadap kandungan lemak kuning telur, tetapi kandungan lemak kuning telur relatif lebih rendah jika dibandingkan dengan perlakuan kontrol. Kandungan lemak dari telur juga dipengaruhi oleh kandungan nutrisi dari ransum ayam petelur. Berdasarkan hasil analisis kandungan lemak ransum yaitu 2.64\% dan kandungan lemak limbah jamu yaitu $2.77 \%$. Standar Nasional Indonesia (2006) menyatakan bahwa kebutuhan lemak kasar untuk ayam ras petelur berkisar $7 \%$. Rendahnya kandungan lemak dari ransum dan limbah jamu dapat menyebabkan rendahnya kandungan lemak kuning telur juga, karena komposisi lemak ransum menggambarkan komposisi asam lemak telur $\mathrm{Hal}$ ini sesuai dengan pendapat Galea (2011) yang menyatakan bahwa profil lemak kuning telur berkaitan dengan profil asam lemak ransum.

Data hasil rataan kandungan kolesterol kuning telur pada Tabel 3. dan hasil analisis ragam menujukkan adanya perbedaan yang nyata $(\mathrm{P}<0.05)$ tehadap kandungan kolesterol kuning telur. Hasil penelitian menunjukkan bahwa terjadi penurunan kadar kolesterol pada perlakuan T2 dan T3 dimana pemberian sinbiotik sebanyak $1 \%$ dan $1,5 \%$. Kadar kolesterol kuning telur hasil penelitian masih dalam standar normal, hal ini berdasarkan dari hasil penelitian Lim et al. (2005) bahwa kadar kolesterol pada kuning telur yaitu $14.79 \mathrm{mg} / \mathrm{g}$. Kandungan kolesterol kuning telur hasil penelitian ini relatif lebih rendah jika dibandingkan dengan hasil penelitian Ariyani (2006) bahwa ayam petelur coklat menghasilkna kandungan kolesterol sebesar $17.08 \mathrm{mg}$ per gram kunig telur. Hasil penelitian Kompiang (2009) menyatakan bahwa mekanisme penurunan kandungan kolesterol kuning telur belum diketahui, namun kemungkinan mikroba dalam probiotik memanfaatkan kolesterol yang terdapat dalam pakan untuk metabolismenya sendiri, sehingga jumlah kolesterol yang tersedia untuk inangnya itu menurun.

Hasil penelitian ini menunjukkan bahwa pemberian sinbiotik dapat memberikan efek baik karena menyebabkan menurunnya kandungan kolestrol kuning telur. Penurunan kadar kolesterol pada kuning telur memberikan indikasi yang baik karena semkain rendah kandungan kolesteol telur maka kualitas telur akan meningkat selain itu juga mengurangi resiko terkena atherosclerosis bagi konsumennya (Rahayu, 2003). Hasil penelitian ini sesuai dengan hasil penelitian Galik et al. (2014) yang menunjukkan bahwa pemberian aditif dalam pakan ayam petelur berpengaruh signifikan terhadap kandungan kolesterol kuning telur, pemberian aditif mampu menurunkan kandungan kolesterol 
kuning telur. Hal ini sesuai dengan penelitian Kompiang (2009) bahwa pemberian probiotik berdampak positif terhadap kualitas produk daging dan telur dengan kandungan kolesterol lebih rendah, serta bebas residu antibiotik Salmonella atau patogen lain.

\section{KESIMPULAN}

Penggunaan sinbiotik sebagai aditif pakan ayam petelur tidak berpengaruh terhadap kandungan protein putih telur, lemak kuning telur dan kolesterol kuning telur.

\section{DAFTAR PUSTAKA}

Ariyani, E. 2006. Penetapan kandungan kolesterol dalam kuning telur pada ayam petelur. Temu Teknis Nasional Tenaga Fungsional Pertanian. Balai Penelitian Ternak, Bogor.

Bell, D. and Weaver. 2002. Commercial Chicken Meat and Egg. Kluwer Academic Publishers, United States of America.

Bologa, M., I. M. Pop and A. Albu. 2009. Research on chemical composition of chicken egg from different system of production (conventional and organic). J. Lucrari Stiintifice-Seri Zootehnie. University of Agricultural Sciences and Veterinary Medicine lasi. 59: $80-85$.

Galea, F. 2011. Nutrition and food management and their influence on egg quality. Simposio Cientifico De Avicultura. 48.

Galik, B., H. Arpasova, D. Biro dan M. Rolinec. 2014. The effect of dietary rhus coriara L. On table eggs yolk nutrients composition. Acta fytotechn. Zootechn 17 (3) : 93 - 95.

Haryati, T. 2011. Probiotik dan Prebiotik sebagai pakan imbuhan nonruminansia. Wartazoa 21(3) : 125 - 132.

Indreswari, R., H. I. Wahyuni, N. Suthama dan P. W. Ristiana. 2009. Pemanfaatan kalsium untuk pembentukan cangkang telur akibat perbedaan porsi pemberian ransum pagi dan siang hari pada ayam petelur. J. Indonesian Trop. Anim. Agric. 34(2) : 134 - 138.

K. S. Lim, S. J. You, B. K. An and C. W. Kang. 2005. Effect of dietry garlic powder and cooper on cholesterol content and quality characteristics of chicken eggs. Animal Resources Research Center, College of Animal Husbandry, Konkuk University.

Kompiang, I. P., 2009. Pemanfaatan mikroorganisme sebagai probiotik untuk meningkatkan produksi ternak unggas di Indonesia. Pengembangan Inovasi Pertanian 2 (3) : $177-191$.

Lai, K. M., Y. S. Chuang, Y. C. Chou, Y. C. Hsu, Y. C. Cheng, C. Y. Shi, H. Y. Chi and K. C. Hsu. 2010. Change in physucochemical properties of egg white and yolk protein from duck shell eggs due to hydrostatic pressure treatment. Poulry Science 89: 729 737.

Muharlien. 2010. Meningkatkan kualitas telur melalui penambahan teh hijau dalam pakan ayam petelur. J. Ilmu dan Teknologi Hasil Ternak 5 (1) : 21 - 37.

Nuriyasa, I. M., E. Puspani dan I. G. N. 2010. Peningkatan efisiensi produksi ayam petelur melalui peningkatan kenyamanan kandang di Desa Bolangan. Udayana Mengabdi. Sumatera. 9 (2) : $55-58$.

Rahayu, I. H. S. 2003. Karaketristik fisik, komposisi kimia dan uji organoleptik telur ayam merawang dengan pemberian pakan bersuplemen omega-3. J. Teknologi dan Industri Pangan XIV (3) : 199 - 205

Sathya, C. dan P. Muruguian. 2015. Effect of dietary supplementation of probiotic and Curculigo orchioides rhizome powder on egg quality parameters and biochemical composition of Japanese quail (Coturnix coturnix japonica). International Journaal of Advances in 
Phaemacy, Biology and Chemistry. 4 (1) : $162-170$.

SNI 01-3907-2006. 2006. Standar Nasional Indonesia. Badan Standarisasi Nasional (BSN).

Suprijatna, E., U. Atmomarsono dan R. Kartasudjana. 2008. Ilmu Dasar Ternak Unggas. Penebar Swadaya. Jakarta.

Tolik, D., E. Polawsika, A. Charuta, S. Nowaczewski and R. Cooper. 2014. Characteristic of egg part, chemical composition and nutritive value of Japanese Quail eggs. Folia Biologica 62 ( 4) : $287-292$.

Ujilestari, T. 2015. Pengaruh penggunaan tepung limbah rumput laut (Gracilaria verrucosa) terfermentasi dalam ransum terhadap kualitas kimiawi telur puyuh (coturnix cotirnix japonica). Fakultas Peternakan dan Pertanian, Universitas Diponegoro. Semarang (Skripsi).

Zainudin, D. 2006. Tanaman obat meningkatkan efisiensi pakan dan kesehatan ternak unggas. Balai Penelitian Ternak. Bogor.

Zeweil, H. S., S. G. Genedy and M. Bassiouni. 2005. Effect of probiotic and medical plant supplements on the production and egg quality of laying Japanese quail hens. Faculty of Agri. (Saba Basha), departement of Animal and Fish Food. Alexandria University. 